\title{
GRAVITY AND MAGNETIC MAPS OF PART OF THE DRENCHWATER CREEK STRATIFORM ZINC-LEAD-SILVER DEPOSIT, HOWARD PASS QUADRANGLE, NORTHWESTERN BROOKS RANGE, ALASKA
}

by

Robert L. Morin 1

\section{Open-File Report 97-705}

This report is preliminary and has not been reviewed for conformity with U.S. Geological Survey editorial standards or with the North American Stratigraphic Code. Any use of trade, firm, or product names is for descriptive purposes only and does not imply endorsement by the U.S. Government.

1997

1 U.S. Geological Survey, Menlo Park, CA 


\section{CONTENTS}

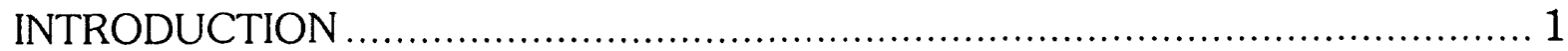

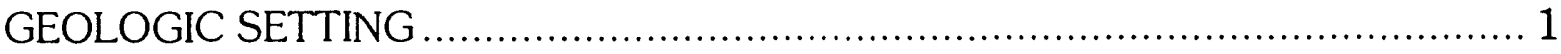

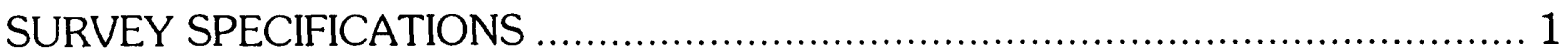

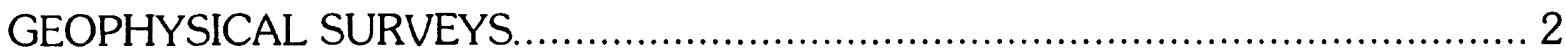

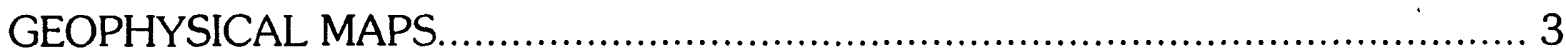

GEOPHYSICAL INTERPRETATION ....................................................... 3

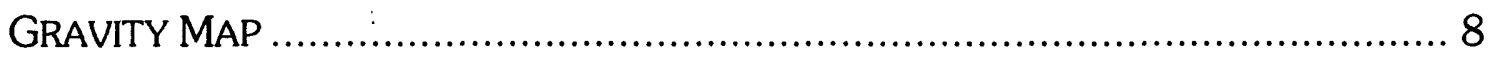

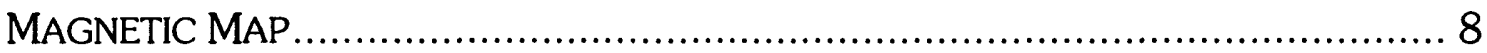

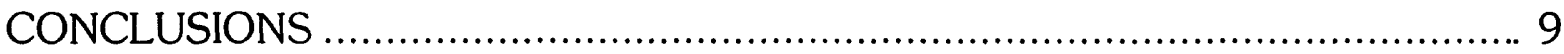

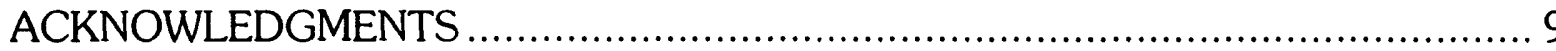



\section{ILLUSTRATIONS}

FIGURE 1. GEOLOGIC MAP.................................................................. 4

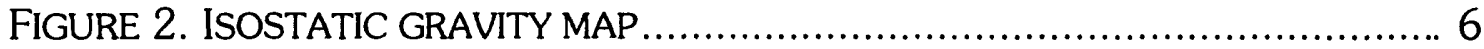

FIGURE 3. MAGNETIC MAP............................................................. 7 


\section{INTRODUCTION}

Gravity and magnetic surveys of a part of the Drenchwater Creek stratiform zinc-lead-silver deposit were made in the summer of 1991. The field work was performed as part of a U.S. Geological Survey (USGS) mineral resource study of the Howard Pass quadrangle in conjunction with studies being carried out by the U.S. Bureau of Mines of the Colville Mining District. The area of this survey ranges from about $68^{\circ} 34^{\prime} 00^{\prime \prime}$ to $68^{\circ} 34^{\prime} 30^{\prime \prime} \mathrm{N}$. lat. and $158^{\circ} 40^{\prime} 48^{\prime \prime}$ to $158^{\circ} 42^{\prime} 12^{\prime \prime} \mathrm{W}$. long and is located on the Howard Pass C-5 1:63,360 scale USGS topographic map.

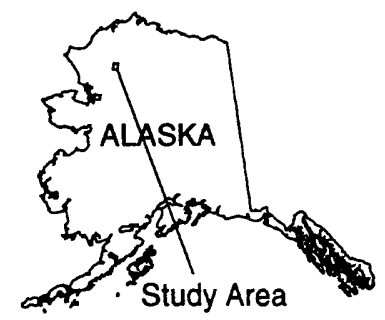

\section{GEOLOGIC SETTING}

The Drenchwater Creek area has been divided into five thrust plates based on rock types and structure (Nokleberg and Winkler, 1982). The Drenchwater plate is characterized by tuff containing sphalerite and galena, a tuffaceous sandstone, and keratophyre flows. Mineralization in the Drenchwater thrust plate occurs in Mississippian through Cretaceous rocks of the Kuna, Siksikpuk, Otuk, and Okpikruak Formations, and in several unnamed rock units of Mississippian and Pennsylvanian (?) age (Kurtak and others, 1995). Mineralization within this study area has been identified mainly in black silicified mudstone in the Mc unit of the Kuna Formation (fig. 1) although trace mineralization occurs in some volcanic rocks.

\section{SURVEY SPECIFICATIONS}

For the purpose of geologic mapping and geochemical sampling, a grid was established over part of the Drenchwater thrust plate of Nokleberg and Winkler (1982) by the U.S. Bureau of Mines. This grid lies between Drenchwater Creek and False Wager Creek which is an unnamed creek on the USGS 1:63,360-scale topographic map Howard Pass (C-5). False Wager Creek is located approximately half way between Drenchwater Creek and Wager Creek. Only the part of the grid that was 
completed at the time of these surveys have gravity and magnetic measurements. This part of the grid is about $700 \mathrm{~m}$ by $700 \mathrm{~m}$. The grid base line at the time of the geophysical surveys was $610 \mathrm{~m}(2000 \mathrm{ft})$ long and oriented about $\mathrm{N} 70^{\circ} \mathrm{W}$. Lines perpendicular to the base line are spaced $122 \mathrm{~m}(400 \mathrm{ft})$ apart. Points along these lines were surveyed at $30 \mathrm{~m}$ (100 ft) intervals for from $274 \mathrm{~m}(900 \mathrm{ft})$ to $366 \mathrm{~m} \mathrm{(1200}$ $\mathrm{ft}$ ) in each direction from the base line.

The grid was established using a compass and a small optical clinometer designed for coarse surveying. One of the grid lines was resurveyed using a precision laser surveying system, which showed that distance measurements between points were quite accurate, but the elevations averaged about $0.3 \mathrm{~m}(1 \mathrm{ft})$ too high for each $30 \mathrm{~m}(100 \mathrm{ft})$ of distance. For purposes of the reducing the gravity data, one foot of elevation was removed from the reported elevations for each $30 \mathrm{~m}(100 \mathrm{ft})$ distance a point was from the starting point of the grid. A gravity map was made with each elevation set for comparison. The gravity map with the modified elevations was much more interpretable.

Further modification of the grid was made by locating the starting point of the grid by triangulation and rotating the grid to align a prominent hill in the northeast part of the grid. An additional north-trending line was surveyed using the laser surveying equipment to the west of the of the grid. This line is about $200 \mathrm{~m}$ long and crosses what is referred to as Discovery Creek. This part of the study area contains visible galena and sphalerite in rubble and has been called the Discovery outcrop. Several additional points were surveyed along a line $91 \mathrm{~m}(300 \mathrm{ft})$ south and parallel to the base line. These points were established at $30 \mathrm{~m}(100 \mathrm{ft})$ intervals and extended $91 \mathrm{~m}(300 \mathrm{ft})$ west and east of the west edge of the grid. The entire pre-existing grid with the exception of a few grid points that had surveyed locations, but the stakes could not be located, were used as locations of both gravity and magnetic measurements. All of the additional surveyed locations were also used as gravity stations, but only the new north-trending line to the west of the original grid has magnetic readings.

\section{GEOPHYSICAL SURVEYS}

The gravity survey was conducted with a LaCoste \& Romberg model G gravity meter. Observed gravity is a measurement of the actual gravity field at the location of a gravity measurement. These values are calculated based on the difference in gravity meter readings between a point with known observed gravity and a new point. 
Corrections to the gravity meter readings are made for instrument calibration constants, instrument drift, and earth tides. Establishing a new gravity base requires making measurements between an old base and a new base. These measurements are called ties and the more ties are made between old and new bases, the more accurate the value of the new base becomes. The observed gravity of the base station used for this survey was calculated based on ties to gravity base station FBKI (Barnes, 1968) at Fairbanks International Airport. The observed gravity of the data collected for this survey are accurate to about $0.04 \mathrm{mGal}$ relative to the local gravity base station. The gravity data were reduced with a density of $2.67 \mathrm{~g} / \mathrm{cm}^{3}$, referenced to the IGSN-1971 datum (Morelli, 1974), and using the 1967 ellipsoid (International Association of Geodesy, 1971). Additional corrections are made for elevation, latitude, terrain, and isostatic compensation. The resulting values are called anomalies and are used in producing gravity maps, profiles, etc. Magnetic data were collected with a Geometrix proton precession magnetometer, which can detect changes in magnetic fields as small as $1 \mathrm{nT}$. The readings from this magnetometer are in total-field units and require only drift and datum corrections.

\section{GEOPHYSICAL MAPS}

The original grid points and the additional surveyed points were converted to latitude and longitude with an accuracy of about 0.001 minutes. The isostatic gravity anomaly data were gridded with an interval of $5 \mathrm{~m}$ between rows and columns using the principle of minimum curvature (Briggs, 1974) and contoured at $0.1 \mathrm{mGal}$ (fig. 2). The magnetic data were gridded with an interval of $5 \mathrm{~m}$ and contoured at $2 \mathrm{nT}$ (fig. 3).

\section{GEOPHYSICAL INTERPRETATION}

A geologic map (fig. 1), an isostatic gravity map (fig. 2), and a magnetic map (fig. 3) are registered on succeeding pages so that direct comparison of each map with any other can be easily made. The correlation and description of map units is located following the geologic map. A detailed gravity and magnetic profile was measured across the Discovery outcrop. This profile can be seen in the western part of figures 1,2 , and 3. The Discovery outcrop (fig. 1) is the area where the most and highest grade mineralization has been observed. The strike of the mineralization is about $\mathrm{N}$. $70^{\circ} \mathrm{W}$. 

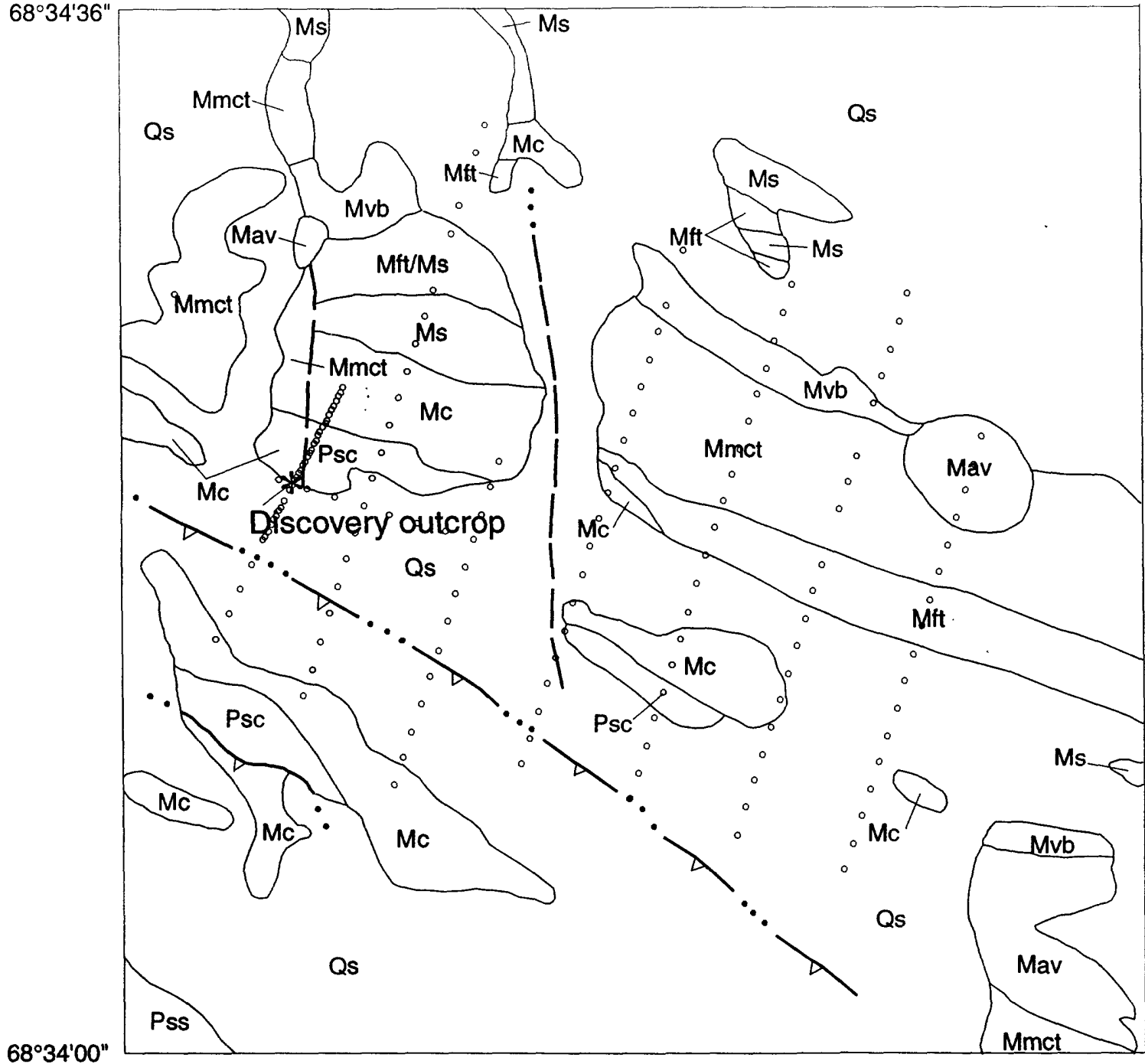

0 $500 \mathrm{M}$

FIGURE 1. Geologic map of the immediate Drenchwater mineralized area, entirely within the Drenchwater plate of Nokleburg and Winkler (1982). Geology mapped by M. Werdon from Kurtak and others (1995). 


\section{CORRELATION OF MAP UNITS}

Unconformity or fault
Mc Mss
Conformable (?) or faulted

Qs Surfical deposits (Quaternary)-Undifferentiated alluvium, colluvium, glacial deposits, talus, and gravel.

Siksikpuk Formation (Permian; may range from Triassic to Pennsylvanian)-(Mull and others, 1982).

Pss Red and green siliceous shale-Strongly cleaved and locally intensely folded and faulted.

Psc Yellow, green, and gray chert-Medium bedded, with dark-gray fresh surfaces. Contains scattered radiolarians and sparce barite concretions or disseminations.

Kuna Formation and unnamed volcanic units (Mississippian; possibly extends into Pennsylvanian)-Original stratigraphic position of the following units unknown.

Mc Black chert and black to light gray silicified mudstone/shale of the Kuna Formation-Silicified mudstone/shale contains variable amounts of pyrite, marcasite, sphalerite, galena, and barite. Black chert contains radiolarians.

Ms Black shale of the Kuna Formation-Approximately 100-m thick (Tailleur and others, 1966). Intensely faulted and sheared; commonly serving as a detachment surface for minor thrust faults. Locally contains galena, sphalerite, and barite in veins and concretions.

Mft Fine-grained felsic tuff-Maximum thickness $80 \mathrm{~m}$. Weathers bright orange, with light-gray fresh surfaces Contains sparse microphenocrysts of barite and feldspar, angular fragments of black chert, and disseminated pyrite.

Mmct Medium- to coarse-grained felsic tuff-As much as $250 \mathrm{~m}$ thick. Weathers brown where carbonate altered and light greenish-gray where chlorite altered. Fresh surfaces are typically light gray. Contains abundant medium to large feldspar phenocrysts and sparse fine biotite phenocrysts in fine-grained matrix. Locally grades into sandstone composed of tuff grains.

Mvb Volcanic breccia-As much as $50 \mathrm{~m}$ thick. Angular, porphyritic volcanic clasts in a matrix of fine tuff. Locally silicified, clasts occasionally cemented and/or replaced by quartz, sphalerite, and galena.

Mav Porphyritic massive alkaline volcanic units-As much as $80 \mathrm{~m}$ thick. Contains coarse-grained phenocrysts of feldspar and fine-grained biotite phenocrysts in a fine-grained trachytic groundmass. Occurs as sills, flows or small domes. Radiometric age of $319 \pm 17 \mathrm{Ma}$ by K-Ar method on biotite (Tailleur and others, 1966).

\footnotetext{
_.. Fault, dashed where approximate, dotted where concealed

.... Thrust fault (minor), dashed where approximate; dotted where concealed,

barbs on upper plate
}

FIGURE 1.-Continued. Correlation of map units and description of map units from Kurtak and others (1995). 


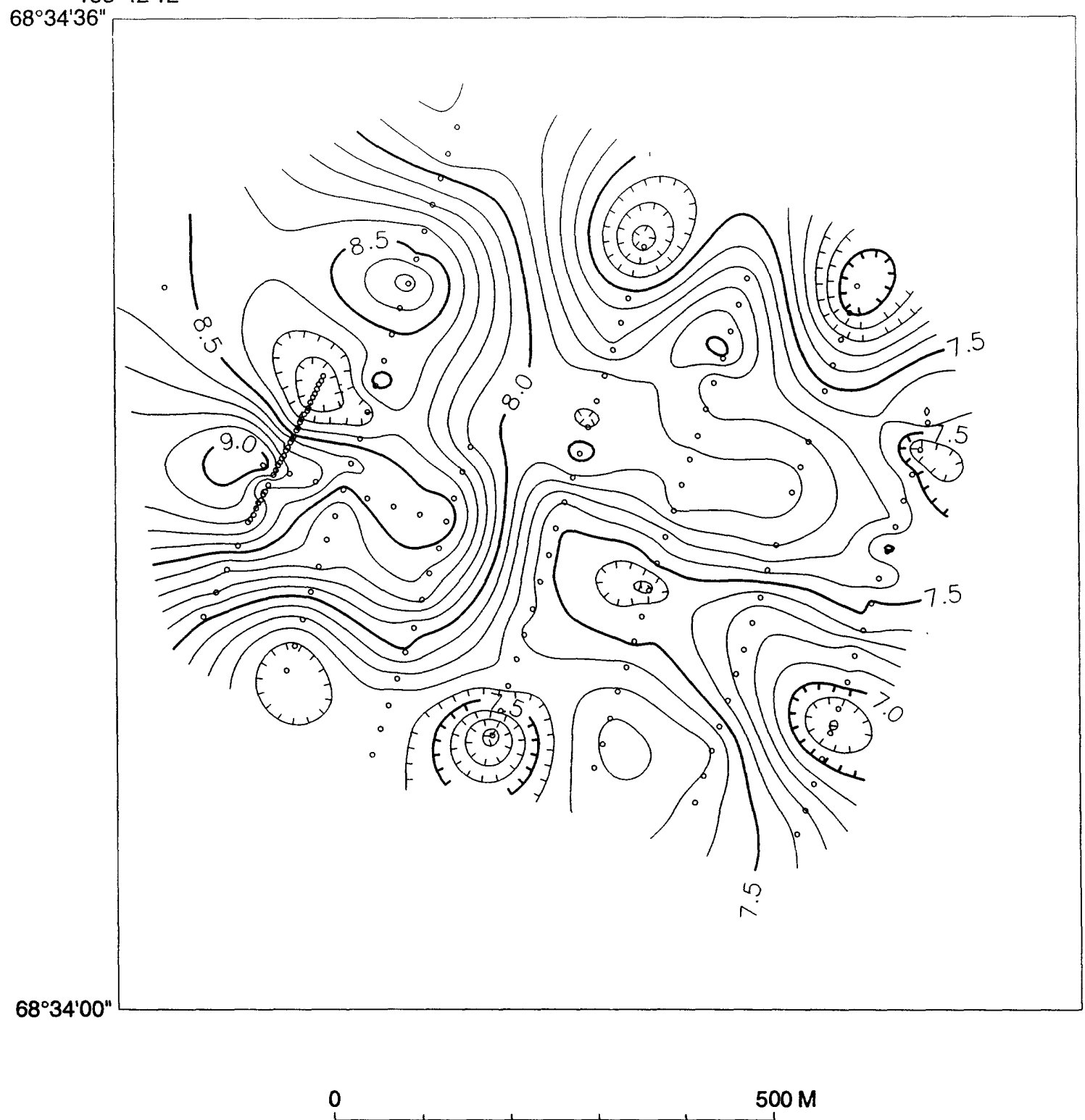

FIGURE 2. Isostatic gravity map of the Drenchwater mineralized area. Contour interval $0.1 \mathrm{mGal}$. Gravity stations are shown as open circles. Closed gravity lows are shown with hachured contours. 


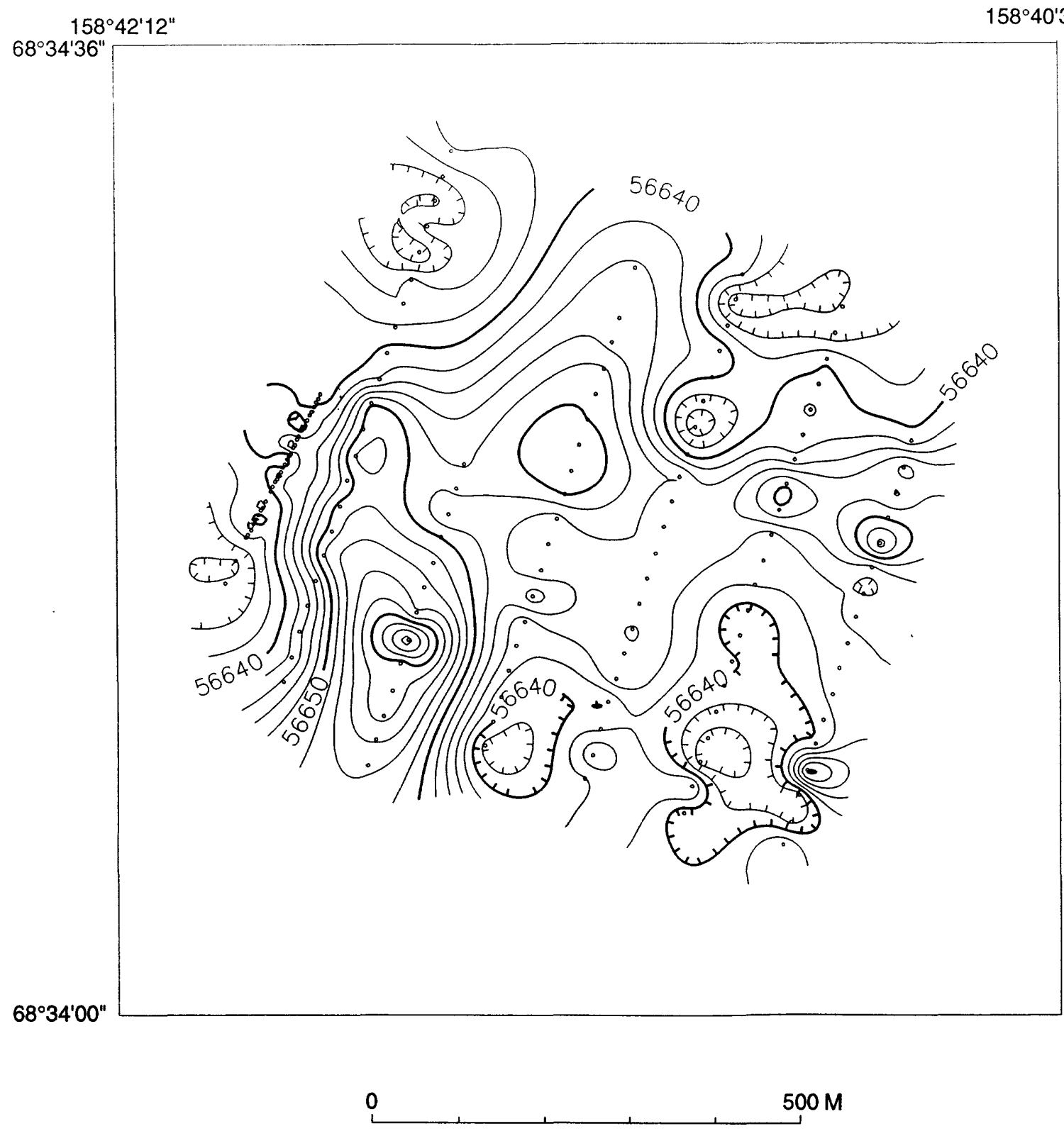

FIGURE 3. Total field ground magnetic map of the Drenchwater mineralized area. Contour interval $2 \mathrm{nT}$. Magnetic stations are shown as open circles. Closed magnetic lows are shown with hachured contours. 


\section{Gravity Map}

The highest gravity values in the study area are located along a gravity ridge which has the same strike as the Discovery outcrop. This gravity high continues to the southeast for about $200 \mathrm{~m}$ from the western end of the gravity survey where it is apparently offset about $150 \mathrm{~m}$ to the north. A similar magnitude gravity high then continues to the southeast. Although the amplitude of the high is decreasing, it appears to extend beyond the study area. If this gravity high is associated with mineralization as it is at the Discovery outcrop, it is possible that mineralization continues along this entire trend, although it may plunge toward the southeast and be buried deeper in the southeast as suggested by the decrease in amplitude of the gravity anomaly. The offset gravity high to the north is coincident with a fault indicated on Werdon's geologic map (fig. 1). Because the gravity map also has a steep gradient along this fault-zone, this fault may be high angle and down to the east along with a northeastern component which accounts for the offset of the gravity ridge. There is also a good correlation between the steep gradient bounding the south side of the gravity ridge west of the indicated cross-fault and a thrust fault striking southeast across the study area (fig 1.). This steep gravity gradient indicates that there is a steep contact in this area which may be related to the mapped fault, but does not appear to be a low angle thrust fault as indicated on Werdon's map. Because the correlation between the gravity gradient and the thrust fault is only apparent along the western part of the fault, there may be an unmapped fault in this area which is nearly vertical as interpreted by Nokleburg and Winkler (1982) of many of the faults and contacts in this area.

\section{Magnetic Map}

The magnetic map (fig. 3) is contoured at $2 \mathrm{nT}$, nearly at the minimum level of confidence of ground magnetic data. The magnetic field is rather flat and this contour interval shows subtle changes in the magnetic field. One of these subtle forms is a magnetic ridge that nearly overlies the gravity ridge which may be associated with the mineralized trend in the study area. This subtle magnetic ridge is truncated at the western end by a magnetic high which appears to be constrained between the two north-trending faults interpreted on the geologic map (fig. 1). The highest part of the 
magnetic high is located at the interpreted thrust fault but is covered by quaternary sediments so the source of the magnetic signal is unknown. This does suggest that the north-trending faults continue to the south, possibly under the thrust fault.

The characteristics of the magnetic ridge east of the western north-trending fault (fig. 1) are very similar to the gravity ridge. The strike of the magnetic ridge is about $\mathrm{N} 70^{\circ} \mathrm{W}$, which is the same strike as the gravity ridge and the same strike as the geologic units in the study area. The offset of the magnetic ridge is about the same as the gravity ridge, but a little farther to the east.

\section{CONCLUSIONS}

Gravity and magnetic surveys over part of the Drenchwater Creek stratiform lead-zinc-silver deposit reveal small geophysical anomalies. These anomalies reflect possible correlation with the known mineralization in Discovery Creek and with the faults interpreted on Werdon's geologic map (fig. 1) (Kurtak and others, 1995). An offset geophysical ridge is located on both the gravity (fig. 2) and magnetic (fig. 3) maps. The offset in the gravity ridge aligns with the eastern N-S fault on Werdon's map. The offset in the magnetic ridge is offset the same distance and direction, but the offset appears to be a little farther to the east. This geophysical ridge is coincident with the known mineralization in the western part of the study area. The gravity data indicate that this ridge is plunging to the east, allowing for the possibility of buried mineralized rocks which is consistent with the geologic interpretation. The large magnetic anomaly on the west side of the study area appears to be constrained by the mapped N-S faults and suggests that these faults extend to the south. The source of this magnetic anomaly is unknown. Additional studies of the physical properties of the rocks in the study area would allow more detailed interpretation of these geophysical maps, specifically, which units are associated with the various geophysical anomalies.

\section{ACKNOWLEDGMENTS}

I wish to acknowledge John Mariano for his assistance in collecting the gravity and magnetic data used in this report. 


\section{REFERENCES CITED}

Barnes, David F., 1968, Alaska gravity base station network: U.S. Geological Survey Open-File Report 68-4. 34 p.

Briggs, I.C., 1974, Machine contouring using minimum curvature: Geophysics, v. 39, p. 39-49.

International Association of Geodesy, 1971, Geodetic reference system 1967: International Association of Geodesy Special Publication no. 3, 116 p.

Kurtak, Joseph M., Hicks, Russell W., Werdon, Melanie B., Meyer, Mark P., and Mull, Charles G., 1995, Mineral investigations in the Colville Mining District and southern National Petroleum Reserve in Alaska: U.S. Bureau of Mines OpenFile Report 8-95. 217 p.

Morelli, C., ed., 1974, The International gravity standardization net 1971: International Association of Geodesy Special Publication no. 4, $194 \mathrm{p}$.

Mull, C.G., Tailleur, I.L., Mayfield, C.F., Ellersieck, I., and Curtis, S., 1982, New Upper Paleozoic and Lower Mesozoic Stratigraphic units, Central and western Brooks Range, Alaska: Am. Assoc. Petroleum Geol. Bulletin, v. 66, no. 7, p 348-362.

Nokleberg, Warren J. and Winkler, Gary R., 1982, Stratiform zinc-lead deposits in the Drenchwater Creek area, Howard Pass quadrangle, northwestern Brooks Range, Alaska: U.S. Geological Survey Profession Paper 1209, 22 p.

Tailleur, I.L., Kent, B.H., and Reiser, H.N., 1966, Outcrop/geologic maps of the Nuka-Etivluk Region, northern Alaska: U.S. Geological Survey Open-File Report 66-128. 